\title{
Metabolic pathway engineering using the central signal processor $\mathrm{P}_{\|}$
}

\author{
Björn Watzer ${ }^{1}$, Alicia Engelbrecht ${ }^{1}$, Waldemar Hauf ${ }^{1}$, Mark Stahl'², |ris Maldener ${ }^{1}$ and Karl Forchhammer ${ }^{1 *}$
}

\begin{abstract}
Background: $P_{\|}$signal processor proteins are wide spread in prokaryotes and plants where they control a multitude of anabolic reactions. Efficient overproduction of metabolites requires relaxing the tight cellular control circuits. Here we demonstrate that a single point mutation in the $\mathrm{P}_{\|}$signaling protein from the cyanobacterium Synechocystis sp. PCC 6803 is sufficient to unlock the arginine pathway causing over accumulation of the biopolymer cyanophycin (multi-L-arginyl-poly-L-aspartate). This product is of biotechnological interest as a source of amino acids and polyaspartic acid. This work exemplifies a novel approach of pathway engineering by designing custom-tailored $\mathrm{P}_{\|}$signaling proteins. Here, the engineered Synechocystis sp. PCC6803 strain with a $\mathrm{P}_{\|}-186 \mathrm{~N}$ mutation over-accumulated arginine through constitutive activation of the key enzyme N-acetylglutamate kinase (NAGK).

Results: In the engineered strain BW86, in vivo NAGK activity was strongly increased and led to a more than tenfold higher arginine content than in the wild-type. As a consequence, strain BW86 accumulated up to 57 \% cyanophycin per cell dry mass under the tested conditions, which is the highest yield of cyanophycin reported to date. Strain BW86 produced cyanophycin in a molecular mass range of 25 to $>100 \mathrm{kDa}$; the wild-type produced the polymer in a range of 30 to $>100 \mathrm{kDa}$.

Conclusions: The high yield and high molecular mass of cyanophycin produced by strain BW86 along with the low nutrient requirements of cyanobacteria make it a promising means for the biotechnological production of cyanophycin. This study furthermore demonstrates the feasibility of metabolic pathway engineering using the $P_{\|}$signaling protein, which occurs in numerous bacterial species.
\end{abstract}

Keywords: Cyanophycin, Cyanobacteria, L-Arginine, $\mathrm{P}_{\|}$protein

\section{Background}

Cyanophycin (multi-L-arginyl-poly-L-aspartate) is a nitrogen/carbon reserve polymer present in most cyanobacteria [1,2] and in a few heterotrophic bacteria $[3,4]$. It consists of a polyaspartic backbone with arginine residues linked via isopeptide bonds at the free carboxylate groups of the aspartic backbone [5, 6]. Cyanophycin is nonribosomally synthesized from arginine and aspartate by cyanophycinsynthetase (CphA) in an ATP-dependent elongation reaction using unidentified primers [6-8]. Cyanophycin accumulates in the cytoplasmic space as

\footnotetext{
*Correspondence: karl.forchhammer@uni-tuebingen.de

${ }^{1}$ Interfaculty Institute of Microbiology and Infection Medicine

Tübingen, Eberhard-Karls-Universität Tübingen, Auf der Morgenstelle 28,

72076 Tübingen, Germany

Full list of author information is available at the end of the article
}

opaque, membrane-less granules [9]. Isolated cyanophycin has a molecular weight widely ranging from 25 to $100 \mathrm{kDa}$ [5] and is insoluble at physiological pH, but soluble in diluted acids or bases [10].

In cyanobacteria, the amount of cyanophycin is usually less than $1 \%$ of the cell dry mass during exponential growth. When cells experience certain unfavorable conditions other than nitrogen starvation, such as stationary phase or unbalanced growth conditions owing to nutrient limitation, e.g., sulfate or phosphate starvation [11], light stress, low temperature [12], or presence of chloramphenicol [13], the cyanophycin content may increase to $18 \%$ of the cell dry mass. Cyanophycin also can accumulate transiently during the recovery of nitrogen-starved, non-diazotrophic cyanobacteria upon addition of a usable nitrogen source [14]. Furthermore, 
in heterocysts (specialized cells for nitrogen fixation) of cyanobacteria of the order Nostocales, polar nodules consisting of cyanophycin are deposited at the contact site to adjacent vegetative cells [15].

The cyanobacterial $\mathrm{P}_{\mathrm{II}}$ protein is a member of the widely distributed family of $\mathrm{P}_{\mathrm{II}}$ signal transduction proteins present in bacteria, plants, and some archaea [16]. $\mathrm{P}_{\mathrm{II}}$ proteins are largely involved in the regulation of nitrogen assimilatory metabolism. For this purpose, $P_{I I}$ senses the cellular energy level by binding ATP or ADP competitively [17] and senses the state of central carbon/ nitrogen metabolism by binding or lack of binding of the status reporter molecule 2-oxoglutarate (2-OG) [18, 19]. Effector molecule binding results in structural rearrangements of the large surface-exposed T-loops of $\mathrm{P}_{\mathrm{II}}$, its major protein-interaction determinant. In the unicellular freshwater cyanobacteria Synechococcus elongatus PCC 7942 and Synechocystis sp. PCC 6803 during nitrogen starvation, which corresponds with high 2-OG levels, the $\mathrm{P}_{\mathrm{II}}$ protein binds 2-OG and is phosphorylated at the apex of the T-loop at position Ser49; when nitrogen is in excess, which corresponds to 2-OG paucity and therefore no binding of the $\mathrm{P}_{\mathrm{II}}$ protein to 2-OG, Ser49 is dephosphorylated [16, 20].

Depending on the bound effector molecules and the phosphorylation status, $\mathrm{P}_{\mathrm{II}}$ interacts and influences many target proteins, including enzymes, channels, and regulatory proteins $[18,21,22]$. One of the major $\mathrm{P}_{\mathrm{II}}$ target proteins is the enzyme $N$-acetylglutamate kinase (NAGK) [23], which catalyzes the committed step in the cyclic arginine biosynthesis pathway [24]. Under nitrogen excess, $\mathrm{P}_{\mathrm{II}}$ in its non-phosphorylated form binds to NAGK [25], there by strongly enhancing its biosynthetic activity as well as relieving the feedback inhibitory effect of arginine on NAGK activity [18]. In a screening for $\mathrm{P}_{\mathrm{II}}$ variants with altered NAGK binding properties, our laboratory previously identified a variant of the $S$. elongatus PCC $7942 \mathrm{P}_{\mathrm{II}}$ protein with a single amino acid replacement, Ile86 to Asp86, hereafter referred to as $\mathrm{P}_{\mathrm{II}}(\mathrm{I} 86 \mathrm{~N})$, that constitutively binds NAGK in vitro [26]. The variant is a structural mimic of $\mathrm{P}_{\mathrm{II}}$ in the NAGK complex, with its T-loops in a kinked conformation; as a consequence of this special T-loop folding, this variant has a high affinity for NAGK and no longer responds to 2-OG but can bind citrate in vitro [27].

For in vivo studies of the role of $\mathrm{P}_{\mathrm{II}}$ in arginine metabolism, strain Synechocystis sp. PCC 6803 offers the advantage over $S$. elongatus that it produces cyanophycin. In a $\mathrm{P}_{\mathrm{II}}$-deficient mutant of Synechocystis sp. PCC 6803, not only does NAGK remain in a low activity state, but also the transient accumulation of cyanophycin that normally occurs after exposing a nitrogen-starved culture to excess ammonia is impaired [23]. We tested whether the opposite phenotype in Synechocystis sp. PCC 6803 would be possible if we replaced the wild-type $g \ln B$ gene (encoding $\mathrm{P}_{\mathrm{II}}$ ) with a $\ln B$ variant with codon alteration Ile86 to Asp, thereby generating a $\mathrm{P}_{\mathrm{II}}$ variant that constitutively activates NAGK, which could lead to the accumulation of cyanophycin not just transiently, but in high amounts. This metabolic pathway engineering via manipulation of the $\mathrm{P}_{\mathrm{II}}$ signal indeed resulted in a strain that excessively overproduces cyanophycin (Fig. 1).

\section{Results and discussion}

Expression of the $\mathrm{P}_{\text {II }}(186 \mathrm{~N})$ variant in Synechocystis sp. PCC 6803 causes a strong in vivo activation of NAGK

Previous biochemical studies have shown that the $\mathrm{P}_{\mathrm{II}}(\mathrm{I} 86 \mathrm{~N})$ variant of $S$. elongatus PCC 7942 constitutively binds to NAGK in vitro [26]. To test whether this $P_{I I}$ variant affects the in vivo activity of NAGK, we constructed a genomic mutant of Synechocystis sp. PCC 6803 in which the $g \ln B$ gene was replaced by a $g \ln B$ gene carrying the mutation for $I 86 \mathrm{~N}$ together with a spectinomycin resistance cassette via homologous recombination. Complete segregation of the mutation in the polyploidy Synechocystis sp. strain, named strain BW86, was confirmed via PCR (Additional file 1: Figure S1).

To determine in vivo NAGK activity during growth with different nitrogen sources, we cultivated the wildtype Synechocystis sp. PCC 6803 and strain BW86 in BG-11 medium containing either nitrate, ammonia, or no nitrogen source (Fig. 2). NAGK activity was higher in strain BW86 than in the wild-type in all cases; the activity was 2.3-fold higher after growth with nitrate and 3.2-fold higher after growth with ammonium. The nitrogen source, i.e., nitrate or ammonium, did not strongly affect NAGK activity. However, under nitrogen starvation, NAGK activity strongly increased in strain BW86 and decreased in the wild-type, such that the activity was 19.2-fold higher in strain BW86. The low activity of NAGK in the wild-type under nitrogen starvation could be explained by the full phosphorylation of $\mathrm{P}_{\mathrm{II}}$ under these conditions [28] since this prevents $\mathrm{P}_{\mathrm{II}}$-NAGK interaction and thus, the NAGK enzyme would be in an inactive state [25]. Transcriptome studies of Synechocystis show an induced expression of the $\operatorname{gln} B$ and $\arg B$ (encoding NAGK) genes under nitrogen starvation [29]. Such an induced expression would lead to increased levels of $\mathrm{P}_{\mathrm{II}}(\mathrm{I} 86 \mathrm{~N})$ and NAGK. Provided that phosphorylation of $\mathrm{P}_{\mathrm{II}}(\mathrm{I} 86 \mathrm{~N})$ is impaired, this could be the cause of the high NAGK activity shown in Fig. 2, since $P_{I I}$ in its non-phosphorylated state interacts with NAGK and strongly enhances its activity [25]. 


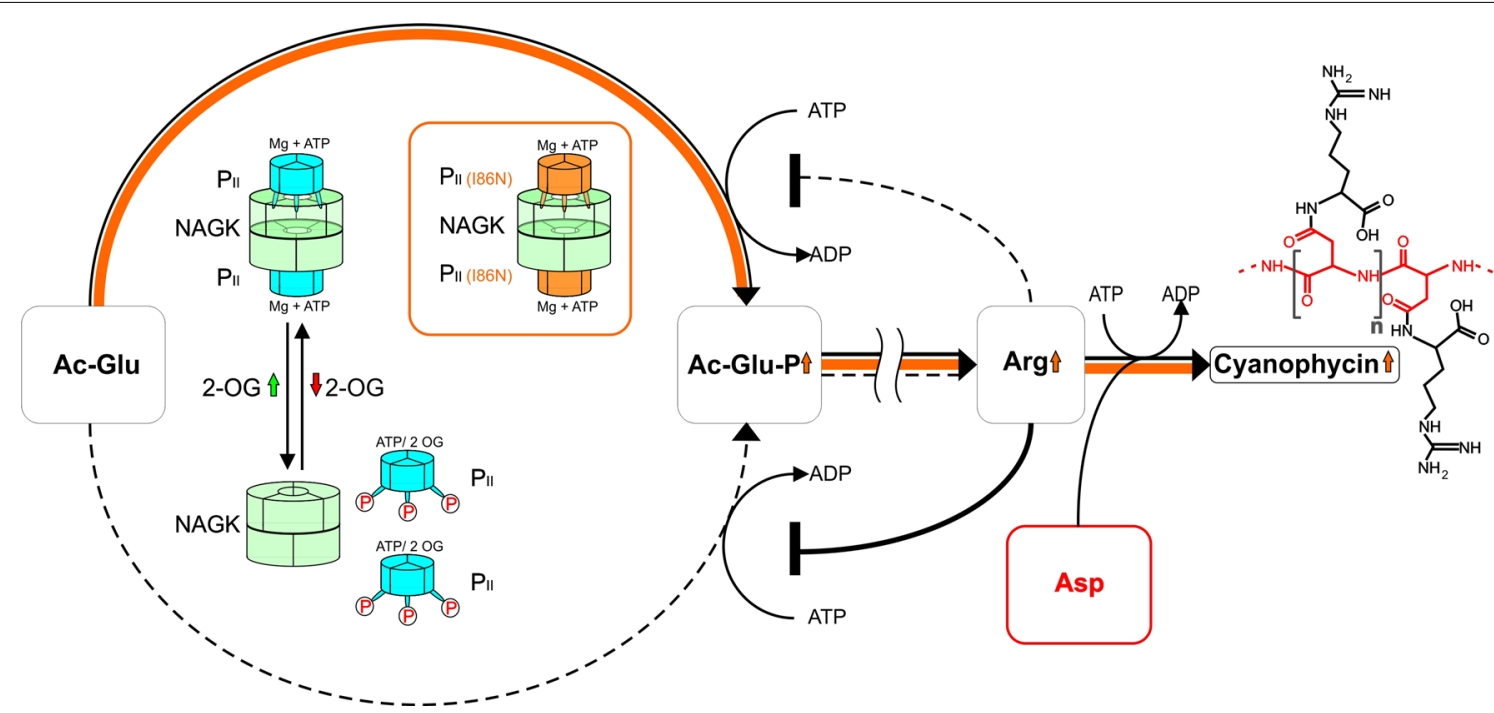

Fig. 1 The strategy of metabolic engineering of the $\mathrm{P}_{\|}(186 \mathrm{~N})$ protein in Synechocystis sp. PCC 6803 for arginine/cyanophycin overproduction. The conversion of $\mathrm{N}$-acetylglutamate (Ac-Glu) to $\mathrm{N}$-acetylglutamate-phosphate (Ac-Glu-P) is the rate-limiting step in the cyclic arginine synthesis pathway and is catalyzed by NAGK. NAGK activity is controlled by complex formation with the $P_{\|}$protein, which senses the nitrogen status by 2-oxogluterate (2-OG) binding. In the wild-type, unbound NAGK has low activity (dashed line) and is highly susceptible to arginine feedback inhibition, whereas NAGK bound to the $\mathrm{P}_{\|}$protein has high activity (solid black line) and much less sensitive towards arginine. The $\mathrm{P}_{\|}(\mathrm{I} 86 \mathrm{~N})$ variant of strain BW86 (in orange box) permanently binds to NAGK and strongly increases its activity (solid orange line) and relieves arginine feedback inhibition. When excess arginine (Arg) is produced cyanophycin is synthesized from arginine and aspartate (Asp in red)

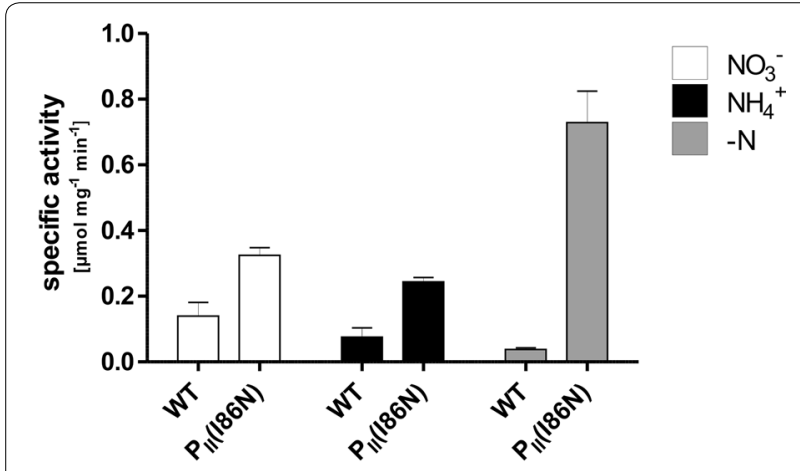

Fig. 2 NAGK specific activity in extracts of Synechocystis sp. PCC 6803 (wild-type) and the engineered strain BW86 incubated with nitrate $\left(\mathrm{NO}_{3}{ }^{-}\right)$, ammonium $\left(\mathrm{NH}_{4}{ }^{+}\right)$, or no nitrogen source $(-\mathrm{N})$ until the late exponential phase $\left(\mathrm{OD}_{750}\right.$ of about 0.8). For nitrogen starvation (-N), cells were incubated in nitrate-supplemented BG-11 medium to an $\mathrm{OD}_{750}$ of 0.5 and were then transferred to $\mathrm{BG}-11$ medium without a nitrogen source and incubated for 2 days to an $\mathrm{OD}_{750}$ of 0.8

\section{The $\mathrm{P}_{\mathrm{II}}(\mathrm{I86N})$ variant has a reduced phosphorylation}

To test the assumption that the high activity of NAGK in strain BW86 is due to impaired phosphorylation of $\mathrm{P}_{\mathrm{II}}(\mathrm{I} 86 \mathrm{~N})$, we analyzed its phosphorylation status using non-denaturing PAGE followed by immunoblotting using $\mathrm{P}_{\mathrm{II}}$ specific antibodies [30] (Fig. 3). Each phosphorylation event increases the negative charge of the $\mathrm{P}_{\text {II }}$ protein and, therefore, leads to three isoforms of increasing

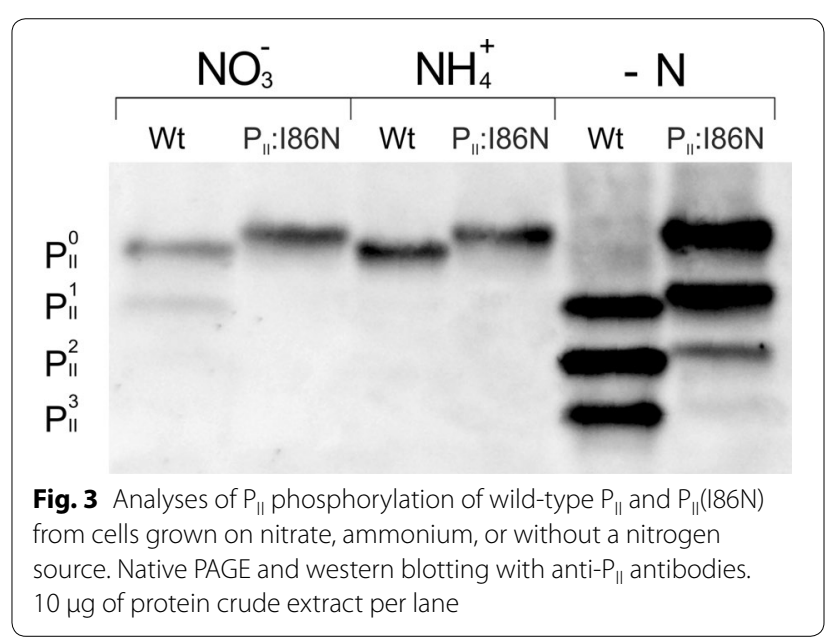

electrophoretic mobility corresponding to one- two- and threefold phosphorylated forms $\left(\mathrm{P}_{\mathrm{II}}^{1}, \mathrm{P}_{\mathrm{II}}^{2}, \mathrm{P}_{\mathrm{II}}^{3}\right)$. The mobility of non-phosphorylated $\mathrm{P}_{\mathrm{II}}(\mathrm{I} 86 \mathrm{~N})$ and wild-type $\mathrm{P}_{\mathrm{II}}$ slightly differed due to the replacement of isoleucine with asparagine at position 86. In nitrate-grown cells, wild-type $\mathrm{P}_{\mathrm{II}}$ was in the non-phosphorylated state $\left(\mathrm{P}_{\mathrm{II}}^{0}\right)$ and in the mono-phosphorylated state $\left(\mathrm{P}_{\mathrm{II}}^{1}\right)$, whereas $\mathrm{P}_{\mathrm{II}}(\mathrm{I} 86 \mathrm{~N})$ was only in the non-phosphorylated state. As expected, both $\mathrm{P}_{\mathrm{II}}$ proteins were non-phosphorylated when the cells were grown with ammonium as nitrogen source. Under conditions of nitrogen starvation, $P_{I I}$ 
in wild-type cells was strongly phosphorylated with the two-and three-fold phosphorylated forms $\left(\mathrm{P}_{\mathrm{II}}^{2}, \mathrm{P}_{\mathrm{II}}^{3}\right)$ prevailing. By contrast, phosphorylation of $\mathrm{P}_{\mathrm{II}}(\mathrm{I} 86 \mathrm{~N})$ was severely impaired, with absence of the fully phosphorylated form $\mathrm{P}_{\mathrm{II}}^{3}$ but dominance of the non-phosphorylated $\left(\mathrm{P}_{\mathrm{II}}^{0}\right)$ and mono-phosphorylated form of $\mathrm{P}_{\mathrm{II}}$. Furthermore, due to the induced expression of $g \ln B$ during nitrogen starvation [21], the bands of wild-type $\mathrm{P}_{\mathrm{II}}$ and $\mathrm{P}_{\mathrm{II}}(\mathrm{I} 86 \mathrm{~N})$ from nitrogen-starved cell are more intensive compared to non-starved cells (Fig. 3). These data confirm that the strikingly high activity of NAGK under nitrogen starvation in strain BW86 (Fig. 2) is due to impaired phosphorylation of $\mathrm{P}_{\mathrm{II}}(\mathrm{I} 86 \mathrm{~N})$.

\section{The high NAGK activity of the $P_{||}(186 N)$ variant leads to a high intracellular arginine level}

NAGK represents a key enzyme in the regulation of arginine biosynthesis and as such its activity is feedback-controlled by the cellular arginine levels, the final product of the pathway. Importantly, in vitro analysis demonstrated that complex formation of NAGK with $\mathrm{P}_{\mathrm{II}}$ not only activates the enzyme, but strongly relieves feedback-inhibition by arginine [26]. To reveal the metabolic changes that are caused by the replacement of wild-type $\mathrm{P}_{\mathrm{II}}$ by the $\mathrm{P}_{\mathrm{II}}(\mathrm{I} 86 \mathrm{~N})$ variant in vivo, we determined the metabolome of the two strains with a focus on metabolites of primary metabolism, i.e., of the TCA cycle, $\mathrm{CO}_{2}$ fixation, amino acid biosynthesis, and glycolysis (Fig. 4). For the comparison an untargeted metabolomics approach was chosen. According to PCA and OPLS-DA analysis (see

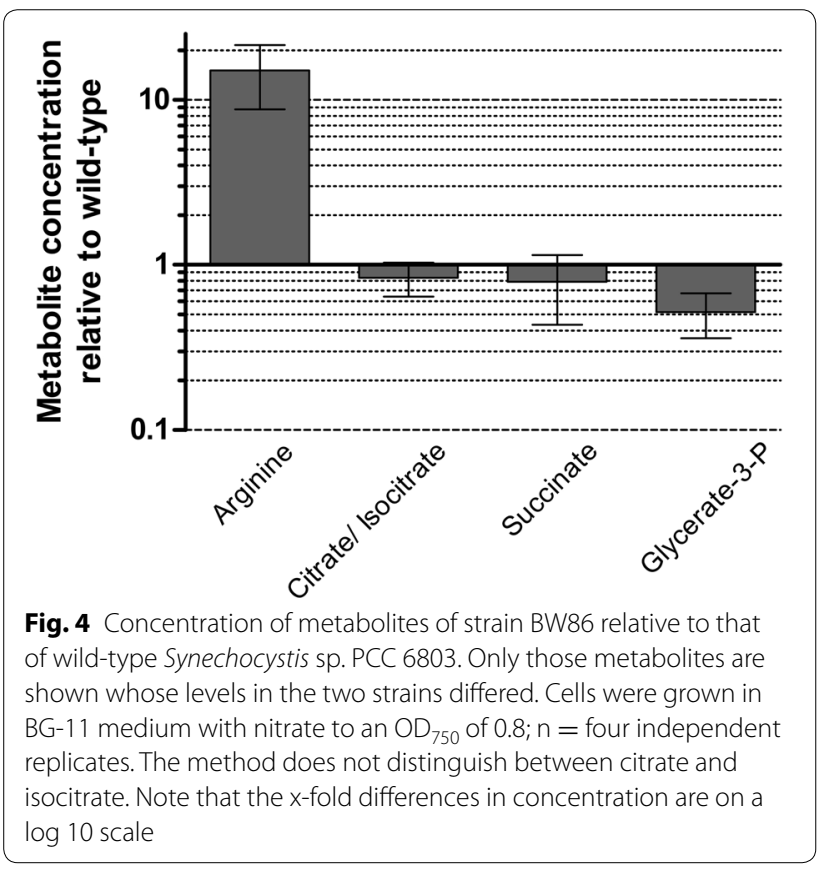

"Methods"), the only changing metabolites are arginine, citrate/isocitrate, succinate and glycerate-3-P. Remarkably, strain BW86 accumulated on average 15-fold more arginine than the wild-type. This increase reflects the constant activation of NAGK by the $\mathrm{P}_{\mathrm{II}}(\mathrm{I} 86 \mathrm{~N})$ variant, which maintains NAGK in a state that is highly insensitive towards arginine-feedback inhibition. On the other hand, the pools of citrate/isocitrate, succinate and glycerate-3-P were decreased. The pools of citrate/isocitrate and succinate were just slightly ( $\mathrm{p}$ value $>0.05$ ) lower in strain BW86 whereas the amount of glycerate-3-P was significantly lower in strain BW86 (p value 0.0107 ). The reason for the decreased level of glycerate-3-P is not known, but it indicates a yet to be explored connection to the increased metabolite flow into the arginine pool, e.g. by accelerated glycolytic flux that could drain the glycerate-3-P pool.

The $P_{\text {II }}(186 N)$ mutation leads to cyanophycin accumulation Previous studies have shown a relationship between a lack of $\mathrm{P}_{\mathrm{II}}$-dependent NAGK activation and a lack of cyanophycin accumulation. It has been suggested that the lack of $\mathrm{P}_{\mathrm{II}}$-induced arginine accumulation disables the accumulation of cyanophycin [23]. As shown above, strain BW86 displays enhanced NAGK activity due to constant NAGK activation by the $\mathrm{P}_{\mathrm{II}}(\mathrm{I} 86 \mathrm{~N})$ variant and in consequence, over produces arginine. It was, therefore, intriguing to elucidate how this affects the accumulation of cyanophycin. Preliminary analysis indicated, that indeed the cellular cyanophycin content was strongly increased. Next, we systematically determined the relationship between nutritional conditions and cyanophycin production (Fig. 5). With nitrate as nitrogen source (Fig. 5a), wild-type cells accumulated about $1.1 \pm 0.5 \%$ cyanophycin relative to the cell dry mass (CDM) in the first 4 days. As the cells entered stationary phase on day 6 up to day 12 (Fig. $5 \mathrm{~A}^{\mathrm{i}}$ ), cyanophycin slightly increased up to $3.6 \pm 0.8 \%$ of the CDM. By contrast, strain BW86 accumulated up to $15.6 \pm 5.4 \%$ cyanophycin relative to the CDM, i.e., on average almost six fold more than the wild-type. Remarkably, upon inoculation of a fresh BW86 culture with stationary cells, the cyanophycin content was initially very high, but the level transiently decreased in the following days, corresponding to the exponential growth phase. After entry into stationary phase, the cyanophycin content increased again.

With ammonium as nitrogen source (Fig. 5b), wildtype cells accumulated cyanophycin similarly as with nitrate as nitrogen source, whereas strain BW86 produced less cyanophycin than in nitrate-supplemented medium, but still considerably more than the wild-type. The cyanophycin level increased up to $9.6 \pm 1.7 \%$ of the CDM in the first 4 days but began to slightly decrease on 

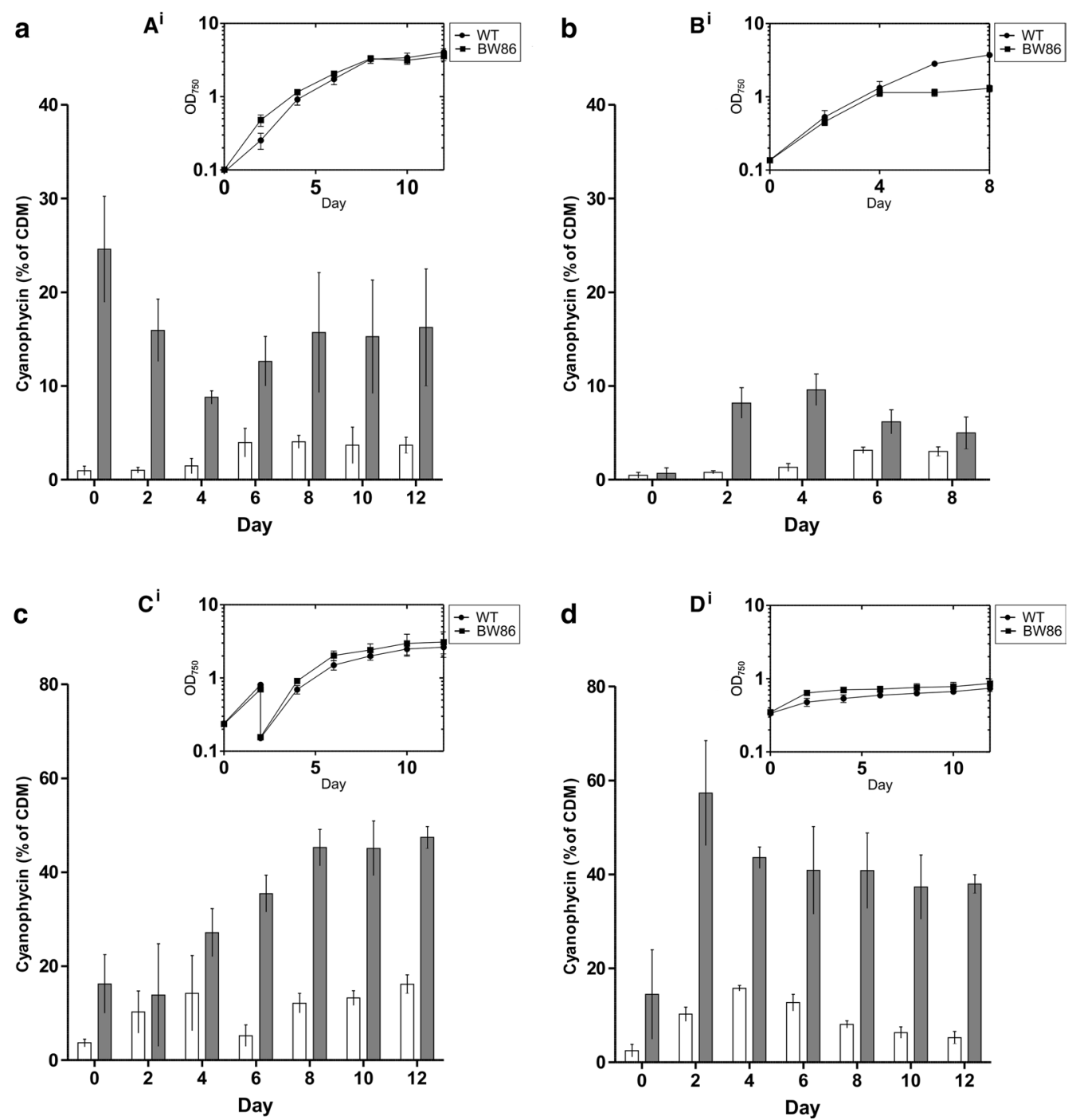

Fig. 5 Cyanophycin accumulation in Synechocystis sp. PCC 6803 wild-type (white bars) and strain BW86 (gray bars) cultivated a with nitrate, b with ammonium, $\mathbf{c}$ under phosphate starvation, and $\mathbf{d}$ under potassium starvation. $A^{i}-D^{i}$ Growth curve of Synechocystis sp. PCC 6803 (WT) (circles) and strain BW86 (squares). Y -axes in log 10 shows the $\mathrm{OD}_{750}$. Cells of each strain exponentially growing in BG-11 medium were inoculated into $800 \mathrm{ml}$ of the respective BG-11 medium and incubated with an influx of $2 \% \mathrm{CO}_{2}$ in air. For phosphate starvation, washed cells were grown in phosphatefree medium and were diluted with fresh phosphate-free medium after 2 days of cultivation; this time point was day 2. For potassium starvation, the cells of the inoculum were washed and inoculated into potassium-free medium. In $\mathbf{c}$ and $\mathbf{d}$, the nitrogen source was nitrate. Cyanophycin was quantified every second day; the concentration is plotted against the cell dry mass (CDM). Note the different scales on the $y$-axes

day 6. Quantification of the amount of ammonium in the medium supernatant of the two strains indicated that strain BW86 consumed ammonia more slowly than the wild-type (Additional file 2: Figure S2). In the first 2 days of cultivation, ammonia consumption of the wild-type and the BW86 strain was similar (Additional file 2: Figure S2). Subsequently, ammonia consumption in strain BW86 ceased. It is conceivable that the initial uptake of ammonium allowed initial cyanophycin accumulation, resulting in a peak of cyanophycin amount at day 2 and 4 (Fig. 5b).
However, since after 4 days the strain BW86 stopped to consume ammonia and to grow (Fig. $5 \mathrm{~B}^{\mathrm{i}}$ ), the cells might have degraded their cyanophycin reserves and used them as internal nitrogen source. The impaired ammonia consumption of strain BW86 could indicate a possible role of $\mathrm{P}_{\text {II }}$ in ammonium utilization, which might be affected in the $\mathrm{P}_{\mathrm{II}}(\mathrm{I} 86 \mathrm{~N})$ variant. In Escherichia coli and many other heterotrophic bacteria, the $\mathrm{P}_{\text {II }}$ homologue GlnK regulates the membrane-localized ammonia transporter $A m t B$ [18]. Although an involvement of cyanobacterial 
$\mathrm{P}_{\mathrm{II}}$ in the regulation of Amt homologues has not yet been clearly demonstrated, such a function seems possible [28]. The phenotype of impaired ammonia utilization observed here could indicate a direct involvement of $\mathrm{P}_{\mathrm{II}}$ in ammonia uptake in Synechocystis sp. as well.

As nitrate-grown cells had higher cyanophycin contents than ammonium-grown cells, we used nitrate as the nitrogen source in the following studies. In some cyanobacterial species, the cyanophycin content can increase up to $18 \%$ of the CDM [11-13,31] under certain stressconditions. Generally, cyanophycin accumulation is triggered by conditions of reduced growth rate, such as entry into stationary phase or unbalanced cultivation conditions, whereas during exponential growth, the amino acids arginine and aspartate are mostly used for protein biosynthesis. To test the effect of growth limitation on cyanophycin accumulation, we starved cells for phosphate or potassium (Fig. 5c, d, respectively).

To induce phosphate starvation cells were washed and inoculated in phosphate free BG-11 medium. Since the internal phosphate pools are only slowly depleted, the cell growth in phosphate free medium is initially not affected. In order to avoid growth into stationary phase without full induction of phosphate starvation, after 2 days, the cultures were again diluted 1:5 in phosphate free medium. After two more days, growth ceases due to phosphate starvation. Accordingly, the cyanophycin content of both strains on day 0 and day 2 (Fig. 5c) is comparable to that of non-starved cells (Fig. 5a). In agreement, the growth rate at this early stage was not affected because of a sufficient internal phosphate pool (Fig. $5 \mathrm{C}^{\mathrm{i}}$ ) [32]. On day 4, the cyanophycin content in both the wildtype and strain BW86 strongly increased, correlating to the onset of the phosphate starvation. After 12 days, the accumulation of cyanophycin was maximal, with the wild-type exhibiting $16.2 \pm 1.9 \%$ of the CDM and strain BW86 $47.4 \pm 2.3 \%$ of the CDM.

Potassium starvation is a very strong and immediate stress for cyanobacterial cells [33] because it is not buffered by internal pools and stringently affects the growth. In the absence of potassium, the growth rate of both strains was nearly zero [33] (Fig. 5D ${ }^{\mathrm{i}}$ ). To test the effect of potassium starvation on cyanophycin production, exponentially growing cells of both strains were washed and inoculated into potassium-free BG-11 medium (Fig. 5d). In contrast to phosphate starvation, the cyanophycin content in potassium-starved cells rapidly increased in the first 2 days, due to the rapid arrest of growth. As long as the metabolism is in an active state, growth arrest allows the efficient synthesis of reserve materials. In agreement, cyanophycin accumulation in the wild-type reached a peak of $15.8 \pm 0.5 \%$ of the CDM after 4 days. In strain BW86, a peak of $57.3 \pm 11.1 \%$ cyanophycin per
CDM was already reached on day 2 . Thereafter, the cyanophycin content of both strains slowly decreased, probably a consequence of a stress response in the decaying cells, caused by the harmful lack of potassium.

\section{Strain BW86 produces cyanophycin of high molecular mass} To test the influence of the $\mathrm{P}_{\mathrm{II}}(\mathrm{I} 86 \mathrm{~N})$ mutation on the cyanophycin polymer length, we isolated cyanophycin granules from cells during the course of a phosphate starvation experiment. We used an extraction method that prevents hydrolyzation of the polymer that normally occurs during the usual acid extraction protocol (see "Methods"). The isolated polymer was solubilized in SDS sample buffer and analyzed by SDS-PAGE (Fig. 6). Cyanophycin isolated from strain BW86 had a size range of 25 to well above $100 \mathrm{kDa}$; the lowest molecular mass was slightly lower than that of the wildtype (range 30 to $>100 \mathrm{kDa}$ ). Like in the wild-type, the time point at which samples were taken had no influence on the size distribution of the polymer. The high molecular weight of cyanophycin produced in strain BW86 is one of the main differences to other recombinant cyanophycin productions strains using heterologous expression systems with heterotrophic bacteria or genetically engineered yeast or plants harboring a cyanobacterial cyanophycin synthetase gene [34-36]. Those strains produce cyanophycin with a size range of only $25-45 \mathrm{kDa}$, but why they fail to produce higher molecular mass cyanophycin has not been elucidated so far. A possible explanation would be that cyanophycin synthesis in the native Synechocystis PCC 6803 background (as is provided in the presently engineered strain BW86) involves additional factors contributing to the polymer length. Further work on the molecular biology of cyanophycin granule synthesis is required to solve this question.

\section{Microscopic examination of cyanophycin production in strain BW86}

The above experiments showed that cells of strain BW86 massively overproduced cyanophycin during exponential growth and even more, under growth-limited conditions, whereas wild-type cells under both conditions produced very little amounts of cyanophycin. To gain insight into the distribution of cyanophycin production in the population of cells of strain BW86, we attempted to microscopically visualize cyanophycin. In previous studies, cyanophycin granules have been recognized by their appearance as light dense granules in bright-field images. Consequently, clear identification of granules is difficult and only large granules could be recognized. The Sakaguchi reaction is a colorimetric reaction for identifying and quantifying arginine [37]. To use the Sakaguchi reaction 


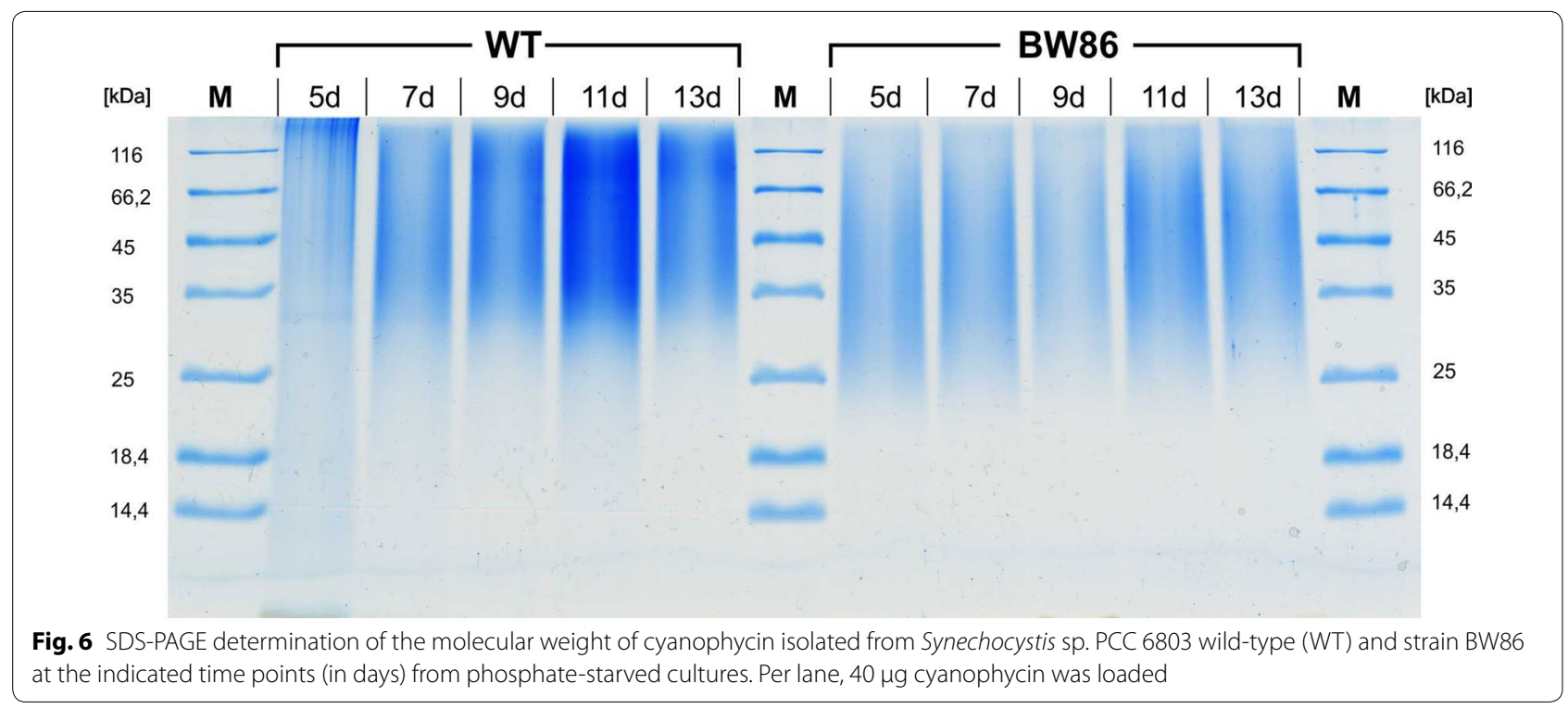

in unicellular cyanobacteria, we developed a fixation protocol that maintained the structure of cells and cyanophycin granules (Fig. 7).

The cytoplasm of exponentially growing wild-type cells stained light red due to the arginine content of cellular proteins. Dark red dots were visible only in very

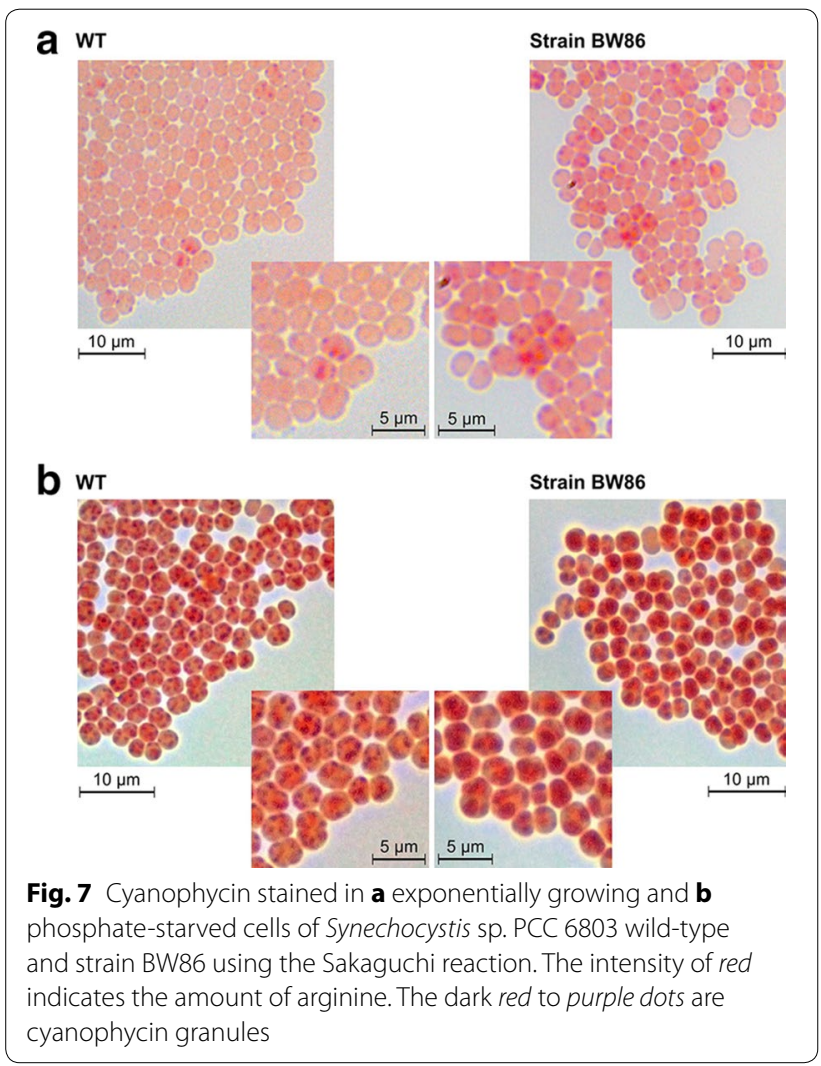

few cells. The intense color of these particles arises presumably from the high arginine content, and they would thus correspond to cyanophycin granules (Fig. 7a). Accordingly, the cytoplasm of cells of strain BW86 was clearly stained darker red due to the higher arginine content as well as more and larger cyanophycin granules, and the granules were heterogeneously distributed. During phosphate starvation, almost all cells, both from the wild-type and strain BW86, produced cyanophycin granules recognizable as dark red dots (Fig. $7 b$ ). The granules in strain BW86 were clearly larger than those in the wild-type; i.e., strain BW86 accumulated a few large cyanophycin granules compared to the small granules in the wild-type. We resolved the granule size in greater detail by examining phosphate-starved cells of wildtype and strain BW86 by transmission electron microscopy (Fig. 8). Cells of strain BW86 contained huge ovoid granules with a scar-like sub-structure (Fig. 8b). To our knowledge, these are the largest cyanophycin granules observed to date. In agreement with the above results, the cyanophycin granules of the wild-type were considerably smaller.

\section{Conclusions}

This work demonstrated the possibility of metabolic engineering using the $\mathrm{P}_{\mathrm{II}}(\mathrm{I} 86 \mathrm{~N})$ variant of the $\mathrm{P}_{\mathrm{II}}$ signal transduction protein to strongly increase arginine levels due to the $\mathrm{P}_{\mathrm{II}}$ dependence of the key enzyme of arginine biosynthesis, NAGK. As a consequence, cells of the engineered strain, strain BW86, overproduced arginine and over-accumulated cyanophycin of high molecular weight. This direct link further supports our previous assumption that cyanophycin synthesis is primarily controlled 

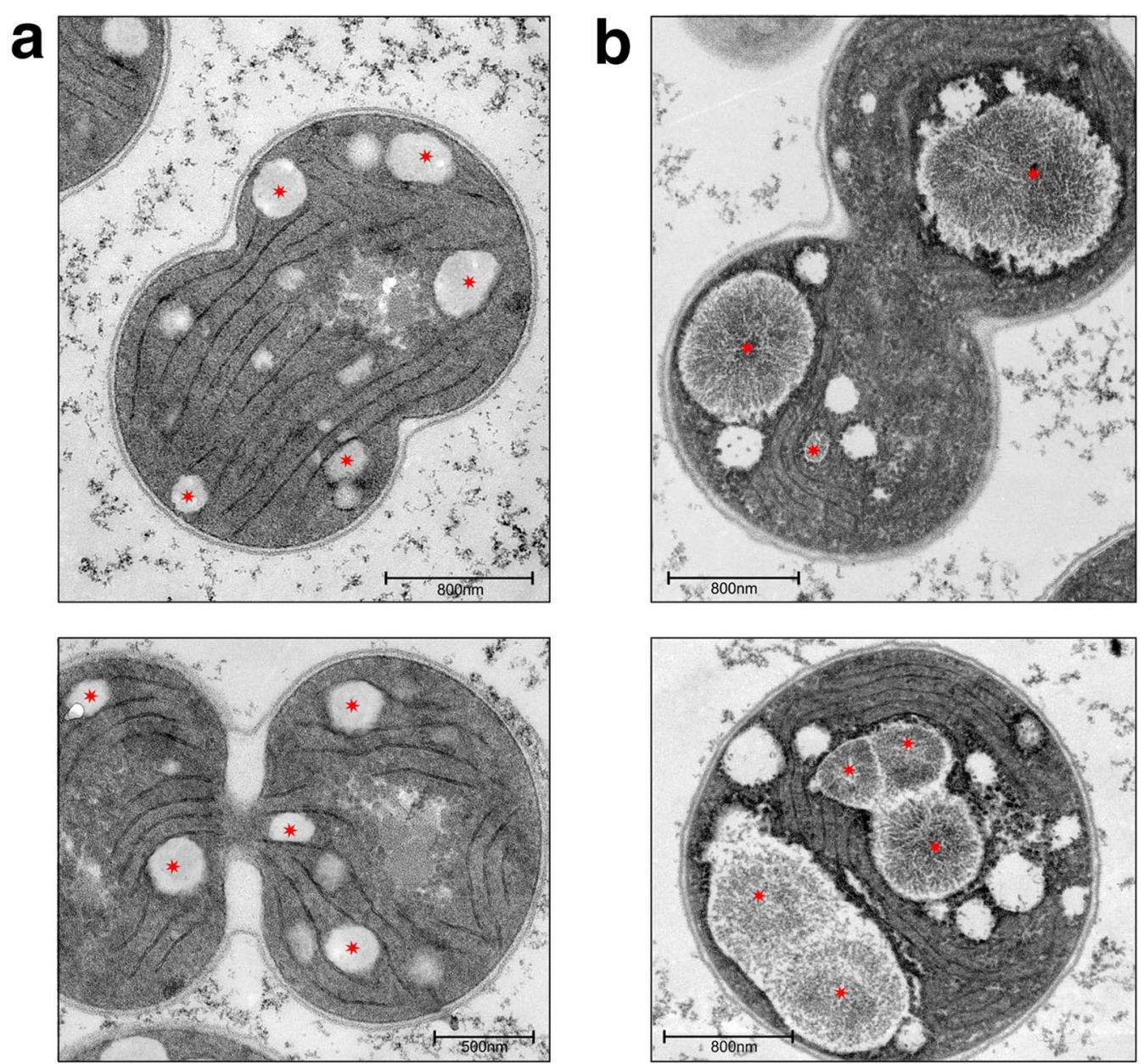

Fig. 8 Transmissionelectron micrographs of ultrathin sections of phosphate-starved $\mathbf{a}$ Synechocystis sp. PCC 6803 wild-type and $\mathbf{b}$ strain BW86. Red asterisks indicate cyanophycin granules

by cellular arginine levels [23]. Taken together, the Synechocystis sp. strain described in this study, strain BW86, is the most potent cyanophycin producer described to date and is, therefore, a promising option for photoautotrophic production of arginine as well as cyanophycin. The large amount of cyanophycin of high molecular weight that can be produced with this strain opens the possibility of investigating novel applications of this polymer for biotechnological purposes.

In addition to the specific benefit of arginine and cyanophycin production obtained with the $\mathrm{P}_{\mathrm{II}}(\mathrm{I} 86 \mathrm{~N})$ variant, this study demonstrated the feasibility of using engineered variants of the $\mathrm{P}_{\text {II }}$ signaling protein for metabolic engineering in bacteria. In addition to arginine synthesis, $\mathrm{P}_{\mathrm{II}}$ controls a multitude of other cellular activities in various autotrophic and heterotrophic bacteria. Therefore, metabolic pathways that are under control of this versatile regulatory protein could similarly be engineered.

\section{Methods}

\section{Cultivation of bacteria}

Standard cloning procedures were done in E. coli XL1Blue (Stratagene) grown in Luria-Bertani medium at $37^{\circ} \mathrm{C}$ with constant shaking at $300 \mathrm{rpm}$.

Cyanobacterial stains were grown photoautotrophically in BG-11 medium [38] containing nitrate or ammonium as nitrogen source and supplemented with $5 \mathrm{mM}$ $\mathrm{NaHCO}_{3}$. Cultures were incubated in 50 or $200 \mathrm{ml}$ medium in 100 or $500 \mathrm{ml}$ Erlenmeyer flasks, respectively, at $28{ }^{\circ} \mathrm{C}$ with constant shaking at $120 \mathrm{rpm}$ and illuminated with $50 \mu \mathrm{mol}$ photons $\mathrm{m}^{-2} \mathrm{~s}^{-1}$. Larger cultures were grown in illuminated cylinders containing $800 \mathrm{ml}$ medium supplemented with $5 \mathrm{mM} \mathrm{NaHCO}, 5 \mathrm{mM}$ TES/ $\mathrm{NaOH}$ pH 8.2 (Roth). The cylinders were constantly aerated by bubbling $2 \% \mathrm{CO}_{2}$ in air through the liquid without additional shaking. Antibiotics were added to the media when required. Growth rates were monitored by measuring the optical density of the cultures at $750 \mathrm{~nm}$. 
Starvation conditions were induced by harvesting, washing, and transferring exponentially growing cells $\left(\mathrm{OD}_{750}\right.$ 0.4-0.5) into BG-11 media lacking a specific nutrient, i.e., no nitrogen source for nitrogen starvation; $\mathrm{K}_{2} \mathrm{HPO}_{4}$ replaced by $\mathrm{KCl}$ for phosphate starvation; and $\mathrm{K}_{2} \mathrm{HPO}_{4}$ replaced by $\mathrm{Na}_{2} \mathrm{HPO}_{4}$ for potassium starvation. In the case of phosphate starvation, after 2 days cultures were diluted again in phosphate-free BG-11 medium to an $\mathrm{OD}_{750}$ of 0.15 to avoid entry into stationary phase before cellular phosphate reserves were exhausted.

\section{Construction of a $\mathrm{P}_{\mathrm{II}}(186 \mathrm{~N})$ mutant}

To construct a genomic $\mathrm{P}_{\text {II }}($ I86N) mutant of Synechocystis sp. PCC 6803, the $\mathrm{P}_{\mathrm{II}}$-encoding gene $\ln B$ was genetically modified with the I86N mutation [Ile (5'ATC) at codon postion 86 to Asp (5'AAC)]. The entire cloning procedure is shown in Additional file 3: Figure S3. To incorporate the corresponding ATC to AAC mutation in the $g \ln B$ gene, two amplicons of $g \ln B$ were made using oligonucleotides $\mathrm{P}_{\mathrm{II}}(\mathrm{I} 86 \mathrm{~N})$ _rev (containing the ATC to

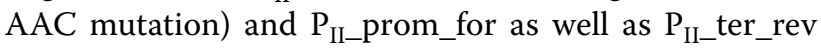
(containing SacI restriction site) and $\mathrm{P}_{\mathrm{II}}(\mathrm{I} 86 \mathrm{~N})$ _for. Both $g \ln B$ amplicons were fused by fusion PCR resulting in the mutated $g \ln B$ amplicon. The genomic region downstream of $g \ln B$ was amplified using slr0402_rev (containing NdeI restriction site) and slr0402_for primers. The mutated $g \ln B$ amplicon was fused with the $\operatorname{slr} 0402$ fragment by fusion PCR and the resulting product was cloned in pJet 1.2 (Fermentas). Subsequently, a spectinomycin resistance cassette and a terminator sequence were inserted between the mutated $g \ln B$ gene and the slr0402 fragment for later selection. A spectinomycin resistance cassette was first amplified using oligonucleotides $\operatorname{spec}^{r}$ for (containing SacI restriction site) and spec $^{r}$ rev and was then fused with a terminator sequence that was, amplified using oligonucleotides Ter_rev (containing NdeI restriction site) and Ter_for. The product was inserted between the SacI and NdeI restriction sites of the $g \ln B$-slr0402 fusion product, resulting in pJet $\mathrm{P}_{\mathrm{II}}(\mathrm{I} 86 \mathrm{~N})$. See Additional file 4: Table $\mathrm{S} 1$ for a list of all oligonucleotides used to generate constructs.

Synechocystis sp. PCC 6803 was transformed with pJet $\mathrm{P}_{\mathrm{II}}(\mathrm{I} 86 \mathrm{~N})$ via natural competence [39]; transformants were selected on BG-11 agar plates supplemented with $25 \mu \mathrm{g} / \mathrm{ml}$ spectinomycin. Transformants were screened for complete segregation via PCR using oligonucleotides $\mathrm{P}_{\mathrm{II}}$ Prom_for and slr0402_for (Additional file 1: Figure S1).

\section{In vivo NAGK activity assay}

Cells $\left(20 \mathrm{ml}\right.$ of a $50-\mathrm{ml}$ culture at an $\mathrm{OD}_{750}$ of 0.8$)$ were rapidly harvested by centrifugation and resuspended in a buffer consisting of $50 \mathrm{mM}$ Tris/ $\mathrm{HCl} \mathrm{pH} \mathrm{7.4,4} \mathrm{mM}$ EDTA, $1 \mathrm{mM}$ DTT, and $0.5 \mathrm{mM}$ benzamidine. Cells were lysed using FastPrep ${ }^{\circledR}$-24 (MP biomedical) with $0.1 \mathrm{~mm}$ glass beads at a speed of $6.0 \mathrm{~m} / \mathrm{s}$ for $20 \mathrm{~s}$ five times. The lysate was separated into soluble and insoluble fractions by centrifugation at $25,000 \times g$ for $25 \mathrm{~min}$ at $4{ }^{\circ} \mathrm{C}$. The protein concentration of the soluble fraction was determined using the Bradford assay [40]. NAGK activity of cell-free extract was measured according to Heinrich et al. [25] using $100 \mu \mathrm{g} / \mathrm{ml}$ protein for each measurement.

\section{Determination of $\mathrm{P}_{\mathrm{II}}$ phosphorylation via western blotting} For non-denaturing electrophoretic separation of proteins, a native Gel was used according to Forchhammer et al. [30]. Per lane, $10 \mu \mathrm{g}$ of crude protein extract was loaded; after electrophoretic separation, the gel was blotted onto a PVDF membrane [41]. The membrane was blocked with TBS blocking buffer $(25 \mathrm{mM}$ Tris/ $\mathrm{HCl} \mathrm{pH}$ 7.4, $75 \mathrm{mM} \mathrm{NaCl})$ containing $1 \%(\mathrm{v} / \mathrm{v})$ Tween 20 overnight at $4{ }^{\circ} \mathrm{C}$. The membrane was washed three times with TBS containing $0.1 \%(\mathrm{v} / \mathrm{v})$ Tween 20 (TBS-T) and afterwards incubated in TBS-T containing the anti- $\mathrm{P}_{\mathrm{II}}$ antibody [20] for $1 \mathrm{~h}$ at ambient temperature. Unbound antibody was removed by washing three times with TBST. Anti-rabbit IgG secondary antibody conjugated to horseradish peroxidase ( $\alpha$-rabbit polyclonal goat antibody, Sigma-Aldrich) diluted 1:10,000 in TBS-T was applied to the membrane and incubated for $30 \mathrm{~min}$ at ambient temperature. Unbound antibodies were removed by three washes with TBS-T. Bound antibodies were visualized using the Lumi Light detection system (Roche Diagnostics). Luminograms were taken with the Gel Logic 1500 imaging system (Kodak) with the associated software.

\section{Metabolite extraction and quantification}

For the extraction of metabolites, cells in $50 \mathrm{ml}$ of culture at an $\mathrm{OD}_{750}$ of 0.8 were shock-cooled by mixing with crushed ice, rapidly harvested by centrifugation, and immediately frozen in liquid nitrogen. After freezedrying, $5.0 \mathrm{mg}$ lyophilized cells were homogenized with tungsten carbide beads in a Retsch Mill MM 200 (Retsch). Metabolites were extracted with $400 \mu \mathrm{l}$ methanol, followed by a second extraction of the cells with $400 \mu \mathrm{l} 20 \%$ methanol with $0.1 \%$ formic acid. The two supernatants were combined; solvents were removed using a vacuum concentrator. Metabolites were re-dissolved in $60 \mu \mathrm{l}$ $20 \%$ methanol with $0.1 \%$ formic acid. A $5 \mu \mathrm{l}$ aliquot was injected on a Waters UPLC/Synapt G2 LC/MS system equipped with a Waters Acquity $2.1 \mathrm{~mm} \times 100 \mathrm{~mm}$, $1.8 \mu \mathrm{m}$ particle size HSS T3 reversed phase column. Metabolites were separated in a gradient from $20 \%$ methanol with $0.1 \%$ formic acid to $100 \%$ methanol with $0.1 \%$ formic acid in $10 \mathrm{~min}$. The mass spectrometer was operated in ESI-positive and -negative modes with a scan range from $\mathrm{m} / z 50$ to 2000 and a dwell time of $0.5 \mathrm{~s}$. Data 
were evaluated using the MarkerLynx Software (Waters Cooperation, Milford, MA, USA) in combination with Simca-P (Umetrics AB Umea, Sweden). Compounds (based on formula and $\mathrm{MS}^{\mathrm{E}}$ fragmentation pattern) that differed between the different samples were identified by principal component analysis (PCA) and Orthogonal projections to latent structures (OPLS)-discriminant analysis (DA). From the entire metabolome, this procedure therefore identifies only those compounds, whose abundance differs between the two analyzed samples.

\section{Cyanophycin extraction and quantification}

Cyanophycin was extracted as described by Elbahloul et al. [42] with some modifications. Briefly, cells in $20-50 \mathrm{ml}$ of culture at an $\mathrm{OD}_{750}$ of $0,1-4$ were harvested by centrifugation, resuspended in $100 \%$ acetone, and incubated for 30 min with constant shaking at $1400 \mathrm{rpm}$. Cells were collected by centrifugation at $25,000 \times g$ for $15 \mathrm{~min}$. The pellet was resuspended in $1.5 \mathrm{ml} 0.1 \mathrm{M} \mathrm{HCl}$ and incubated for $1 \mathrm{~h}$ with constant shaking at $1400 \mathrm{rpm}$ at $60^{\circ} \mathrm{C}$ to solubilize cyanophycin. To remove debris, the sample was centrifuged at $25,000 \times g$ for $15 \mathrm{~min}$. Cyanophycin in the clear supernatant was precipitated by adding $300 \mu \mathrm{l} 1 \mathrm{M}$ Tris/ $\mathrm{HCl} \mathrm{pH} 8.0$ and incubating the mixture for $40 \mathrm{~min}$ at $4{ }^{\circ} \mathrm{C}$. The mixture was then centrifuged at $25,000 \times g$ for $15 \mathrm{~min}$ at $4{ }^{\circ} \mathrm{C}$. The supernatant was discarded, and the pelleted cyanophycin was dissolved in $500 \mu \mathrm{l} 0.1 \mathrm{M} \mathrm{HCl}$. Cyanophycin was quantified by determining arginine using the Sakaguchi reaction according to Messineo [43].

\section{Cyanophycin isolation and determination of molecular mass}

To determine the molecular mass of native cyanophycin, we modified the procedure of Ziegler et al. [3] to avoid hydrolyzation of cyanophycin by acid extraction. Cells were harvested and washed three times in buffer consisting of $50 \mathrm{mM}$ Tris/ $\mathrm{HCl} \mathrm{pH} \mathrm{7.4,} 150 \mathrm{mM} \mathrm{NaCl}$, and $5 \mathrm{mM}$ EDTA. The cell pellet was resuspended in B-Per ${ }^{\mathrm{TM}}$ buffer supplemented with $100 \mu \mathrm{g} / \mathrm{ml}$ lysozyme and $5 \mathrm{U} / \mathrm{ml}$ DNase I. Cells were lysed using FastPrep ${ }^{\circledR}-24$ (MP biomedical) with $0.1 \mathrm{~mm}$ glass beads at a speed of $6.0 \mathrm{~m} / \mathrm{s}$ for $20 \mathrm{~s}$ five times. The lysate was separated into soluble and insoluble fractions by centrifugation at $25,000 \times g$ for $25 \mathrm{~min}$ at $4{ }^{\circ} \mathrm{C}$. The insoluble fraction was washed three times with the same buffer and resuspended in B-Per ${ }^{\mathrm{TM}}$ buffer supplemented with $200 \mu \mathrm{g} / \mathrm{ml}$ proteinase $\mathrm{K}$, which does not degrade cyanophycin, and incubated at $50^{\circ} \mathrm{C}$ overnight. Cyanophycin granules were collected by centrifugation at $25,000 \times g$ for $25 \mathrm{~min}$ at $4{ }^{\circ} \mathrm{C}$ and washed three times with water. Cyanophycin was quantified as described above. To determine the molecular mass, cyanopycin granules were solubilized in SDS-loading buffer and separated by SDS-PAGE on a $12 \%$ polyacrylamide gel according to Sambrook and Russell [44].

\section{Microscopy and cyanophycin staining}

Cyanophycin granules in bacterial cells were visualized microscopically using a newly developed staining method based on the Sakaguchi reaction. Cells of a $500 \mu \mathrm{l}$ culture at an $\mathrm{OD}_{750}$ of $0.1-1.0$ were collected via centrifugation and washed with $2.7 \mathrm{mM} \mathrm{KCl}, 1.5 \mathrm{mM}$ $\mathrm{KH}_{2} \mathrm{PO}_{4}, 137 \mathrm{mM} \mathrm{NaCl}, 8.1 \mathrm{mM} \mathrm{Na}_{2} \mathrm{HPO}_{4}, \mathrm{pH} 6.5$ (PBS buffer). The cells were fixed by resuspending them in $500 \mu \mathrm{l}$ PBS buffer containing $2.5 \%$ (v/v) glutardialdehyde and incubated for $30 \mathrm{~min}$ at $4{ }^{\circ} \mathrm{C}$. After fixation, the cells were washed with PBS and collected by centrifugation at $3000 \times g$ for $8 \mathrm{~min}$ at $4{ }^{\circ} \mathrm{C}$. Then, cells were gently resuspended in $80 \mu \mathrm{l} 5 \mathrm{M} \mathrm{KOH}$ and $10 \mu \mathrm{l}$ of $1 \%$ (w/v) 2,4-dichloro-1-naphthol dissolved in absolute ethanol was added; the mixture was incubated for $2 \mathrm{~min}$ at ambient temperature. Subsequently, $10 \mu \mathrm{l}$ of $4-6 \%$ (v/v) $\mathrm{NaClO}$ was added, and the mixture was incubated for $2 \mathrm{~min}$. Finally, the cells were collected by centrifugation at $3000 \times g$ for $5 \mathrm{~min}$, resuspended in $100 \mu \mathrm{l}$ PBS buffer, and viewed under a Leica DM2500 microscope with a $100 \times / 1.3$ oil objective. Photographs were taken with a Leica DFC420C color camera.

\section{Transmissionelectron microscopy}

Samples for transmissionelectron microscopy were prepared as described in Fiedler et al. [45]. Briefly, samples were fixed and post-fixed using glutaraldehyde and potassium permanganate. The samples were embedded in EPON, and ultrathin sections were stained with uranyl acetate and lead citrate. The samples were examined with a Philips Tecnai electron microscope at $80 \mathrm{kV}$.

\section{Additional files}

Additional file 1: Figure S1. Complete segregation of the mutation in the polyploidy Synechocystis sp. BW86. The replacement of all genomic copies of $g \ln B$ (ss/0707) confirmed via PCR with isolated genomic DNA of Synechocystis sp. BW86, and, as controls, the wild-type Synechocystis PCC 6803 and the pJet 1.2 pJet $P_{\|}(186 \mathrm{~N})$ construct. Wild-type glnB produces a PCR fragment of approximately $1,300 \mathrm{bp}$, whereas the $g \ln B(I 86 \mathrm{~N})$ construct in both pJet 1.2 and strain BW86 produces a PCR fragment of approximately $2,600 \mathrm{bp}$ with no observable wild-type background fragment.

Additional file 2: Figure S2. Ammonium concentration in culture supernatants of the wild-type Synechocystis sp. PCC 6803 (WT) and strain BW86 grown in BG-11 medium with ammonium.

Additional file 3: Figure S3. Cloning schemes for generation of the gene encoding $\mathrm{P}_{\|}(186 \mathrm{~N})$ in Synechocystis sp. PCC 6803 showing all primer binding positions and restriction sites used in the construction. A) Spectinomycin resistance cassette (spec') fused with a terminator sequence (Ter). B) $\mathrm{P}_{\|}$-encoding gene gln $\mathrm{B}$ and downstream open reading frame slr0402. C) Engineered construct encoding $P_{\|}(186 N)$ with spectinomycin resistance cassette inserted downstream of the variant $g \ln B$ gene.

Additional file 4: Table S1. Oligonucleotides used in this study. 


\section{Authors' contributions}

BW planned and performed experiments, analyzed and interpreted the data. AE and WH designed and generated stain BW86. MS performed the metabolomic study. IM performed the transmission electron microscopy. KF supervised the study, designed experiments and analyzed and interpreted the results. BW and KF wrote the manuscript. All authors read and approved the final manuscript.

\section{Author details}

${ }^{1}$ Interfaculty Institute of Microbiology and Infection Medicine Tübingen, Eberhard-Karls-Universität Tübingen, Auf der Morgenstelle 28, 72076 Tübingen, Germany. ${ }^{2}$ Central Facilities, Analytics, ZMBP, Eberhard-Karls-Universität Tübingen, Auf der Morgenstelle 32, 72076 Tübingen, Germany.

\section{Acknowledgements}

This work was supported by the DFG-funded research training group GRK 1708 and by the "Cyanofood" program of the Ministerium für Wissenschaft, Forschung und Kunst Baden-Württemberg. We thank Alexander Klotz and Philipp Spät for help and general discussions. We thank Prof. Oliver Betz for providing TEM facilities, Claudia Menzel for technical assistance, Iris Stärk-Lenk for providing preliminary data, Karen Brune and Bernhard Watzer for carefully reading the paper.

\section{Competing interests}

The authors declare that they have no competing interests.

Received: 28 July 2015 Accepted: 6 November 2015

Published online: 25 November 2015

\section{References}

1. Allen MM. Cyanobacterial Cell Inclusions. Annu Rev Microbiol. 1984;38:1-25.

2. Allen MM. Cyanophycin_-inclusions. Methods Enzymol. 1988;167:207-13.

3. Ziegler K, Deutzmann R, Lockau W. Cyanophycin synthetase-like enzymes of non-cyanobacterial eubacteria: characterization of the polymer produced by a recombinant synthetase of Desulfitobacterium hafniense. Z Naturforsch C. 2002; 57:522-9.

4. Krehenbrink M, Oppermann-Sanio FB, Steinbuchel A. Evaluation of noncyanobacterial genome sequences for occurrence of genes encoding proteins homologous to cyanophycin synthetase and cloning of an active cyanophycin synthetase from Acinetobacter sp. strain DSM 587. Arch Microbiol. 2002;177:371-80.

5. Simon RD. Cyanophycin granules from the blue-green alga Anabaena cylindrica: a reserve material consisting of copolymers of aspartic acid and arginine. Proc Natl Acad Sci USA. 1971;68:265-7.

6. Simon RD. The biosynthesis of multi-L-arginyl-poly(L-aspartic acid) in the filamentous cyanobacterium Anabaena cylindrica. Biochim Biophys Acta. 1976:422:407-18.

7. Aboulmagd E, Oppermann-Sanio FB, Steinbuchel A. Molecular characterization of the cyanophycin synthetase from Synechocystis sp. strain PCC6308. Arch Microbiol. 2000;174:297-306.

8. Berg H, Ziegler K, Piotukh K, Baier K, Lockau W, Volkmer-Engert R. Biosynthesis of the cyanobacterial reserve polymer multi-L-arginyl-poly-L-aspartic acid (cyanophycin): mechanism of the cyanophycin synthetase reaction studied with synthetic primers. Eur J Biochem. 2000;267:5561-70.

9. Allen MM, Weathers PJ. Structure and composition of cyanophycin granules in the cyanobacterium Aphanocapsa 6308. J Bacteriol. 1980;141:959-62.

10. Hegler R. Untersuchungen üiber die Organisation der Phycochromaceenzellen. Jb wiss Bot. 1901;36:234-311.

11. Simon RD. Measurement of the cyanophycin granule polypeptide contained in the blue-green alga Anabaena cylindrica. J Bacteriol. 1973;114:1213-6.

12. Obst M, Steinbuchel A. Microbial degradation of poly(amino acid)s. Biomacromolecules. 2004;5:1166-76.

13. Simon RD. The effect of chloramphenicol on the production of cyanophycin granule polypeptide in the blue green alga Anabaena cylindrica. Arch Mikrobiol. 1973;92:115-22.
14. Allen MM, Hutchison F. Nitrogen limitation and recovery in the cyanobacterium aphanocapsa-6308. Arch Microbiol. 1980;128:1-7.

15. Ziegler K, Stephan DP, Pistorius EK, Ruppel HG, Lockau W. A mutant of the cyanobacterium Anabaena variabilis ATCC 29413 lacking cyanophycin synthetase: growth properties and ultrastructural aspects. FEMS Microbiol Lett. 2001;196:13-8.

16. Forchhammer K. Global carbon/nitrogen control by PII signal transduction in cyanobacteria: from signals to targets. FEMS Microbiol Rev. 2004:28:319-33.

17. Zeth K, Fokina O, Forchhammer K. Structural basis and target-specific modulation of ADP sensing by the Synechococcus elongatus PII signaling protein. J Biol Chem. 2014;289:8960-72.

18. Forchhammer K. P(II) signal transducers: novel functional and structural insights. Trends Microbiol. 2008;16:65-72.

19. Fokina O, Chellamuthu VR, Forchhammer K, Zeth K. Mechanism of 2-oxoglutarate signaling by the Synechococcus elongatus PII signal transduction protein. Proc Natl Acad Sci USA. 2010;107:19760-5.

20. Forchhammer K, Hedler A. Phosphoprotein PIl from cyanobacteria-analysis of functional conservation with the PII signal-transduction protein from Escherichia coli. Eur J Biochem. 1997;244:869-75.

21. Espinosa J, Forchhammer K, Burillo S, Contreras A. Interaction network in cyanobacterial nitrogen regulation: PipX, a protein that interacts in a 2-oxoglutarate dependent manner with PII and NtcA. Mol Microbiol. 2006:61:457-69.

22. Osanai T, Sato S, Tabata S, Tanaka K. Identification of PamA as a PIIbinding membrane protein important in nitrogen-related and sugarcatabolic gene expression in Synechocystis sp. PCC 6803. J Biol Chem. 2005;280:34684-90.

23. Maheswaran M, Ziegler K, Lockau W, Hagemann M, Forchhammer K. Pll-regulated arginine synthesis controls accumulation of cyanophycin in Synechocystis sp. strain PCC 6803. J Bacteriol. 2006;188:2730-4.

24. Caldovic L, Tuchman M. N-acetylglutamate and its changing role through evolution. Biochem J. 2003;372:279-90.

25. Heinrich A, Maheswaran M, Ruppert U, Forchhammer K. The Synechococcus elongatus $\mathrm{P}$ signal transduction protein controls arginine synthesis by complex formation with $\mathrm{N}$-acetyl-L-glutamate kinase. Mol Microbiol. 2004;52:1303-14.

26. Fokina O, Chellamuthu VR, Zeth K, Forchhammer K. A novel signal transduction protein P(II) variant from Synechococcus elongatus PCC 7942 indicates a two-step process for NAGK-P(II) complex formation. J Mol Biol. 2010;399:410-21.

27. Zeth K, Fokina O, Forchhammer K. An engineered PII protein variant that senses a novel ligand: atomic resolution structure of the complex with citrate. Acta Crystallogr D. 2012;68:901-8.

28. Forchhammer K, Tandeau de Marsac N. Phosphorylation of the PII protein ( $g \operatorname{lnB}$ gene product) in the cyanobacterium Synechococcus sp. strain PCC 7942: analysis of in vitro kinase activity. J Bacteriol. 1995;177:5812-7.

29. Krasikov V, AguirrevonWobeser E, Dekker HL, Huisman J, Matthijs HC. Time-series resolution of gradual nitrogen starvation and its impact on photosynthesis in the cyanobacterium Synechocystis PCC 6803. Physiol Plant. 2012;145:426-39.

30. Forchhammer K, Tandeau de Marsac N. The PIl protein in the cyanobacterium Synechococcus sp. strain PCC 7942 is modified by serine phosphorylation and signals the cellular N-status. J Bacteriol. 1994;176:84-91.

31. Allen MM, Hutchison F, Weathers PJ. Cyanophycin granule polypeptide formation and degradation in the cyanobacterium Aphanocapsa 6308. J Bacteriol. 1980;141:687-93.

32. Grillo JF, Gibson J. Regulation of phosphate accumulation in the unicellular cyanobacterium Synechococcus. J Bacteriol. 1979;140:508-17.

33. Alahari A, Apte SK. Pleiotropic effects of potassium deficiency in a heterocystous, nitrogen-fixing cyanobacterium, Anabaena torulosa. MicrobiolUk. 1998;144:1557-63.

34. Shin JH, Lee SY. Metabolic engineering of microorganisms for the production of L-arginine and its derivatives. Microb Cell Fact. 2014;13:166.

35. Steinle A, Oppermann-Sanio FB, Reichelt R, Steinbuchel A. Synthesis and accumulation of cyanophycin in transgenic strains of Saccharomyces cerevisiae. Appl Environ Microbiol. 2008;74:3410-8.

36. Frey KM, Oppermann-Sanio FB, Schmidt H, Steinbuchel A. Technical-scale production of cyanophycin with recombinant strains of Escherichia coli. Appl Environ Microbiol. 2002;68:3377-84. 
37. Deitch AD. An improved Sakaguchi reaction for microspectrophotometric use. J Histochem Cytochem. 1961;9:477-83.

38. Rippka R, Deruelles J, Waterbury JB, Herdman M, Stanier RY. Generic assignments, strain histories and properties of pure cultures of cyanobacteria. J Gen Microbiol. 1979;111:1-61.

39. Grigorieva G, Shestakov S. Transformation in the cyanobacterium Synechocystis sp. 6803. FEMS Microbiol Lett. 1982;13:367-70.

40. Bradford MM. A rapid and sensitive method for the quantitation of microgram quantities of protein utilizing the principle of protein-dye binding. Anal Biochem. 1976;72:248-54.

41. Towbin H, Staehelin T, Gordon J. Electrophoretic transfer of proteins from polyacrylamide gels to nitrocellulose sheets: procedure and some applications. Proc Natl Acad Sci USA. 1979;76:4350-4.
42. Elbahloul Y, Krehenbrink M, Reichelt R, Steinbuchel A. Physiological conditions conducive to high cyanophycin content in biomass of Acinetobacter calcoaceticus strain ADP1. Appl Environ Microbiol. 2005;71:858-66.

43. Messineo L. Modification of Sakaguchi reaction-spectrophotometric determination of arginine in proteins without previous hydrolysis. Arch Biochem Biophys. 1966;117:534-40.

44. Sambrook J, Russell D. Molecular cloning: a laboratory manual. 3rd ed. New York: Cold Spring Harbor Laboratory Press; 2001.

45. Fiedler G, Arnold M, Hannus S, Maldener I. The DevBCA exporter is essential for envelope formation in heterocysts of the cyanobacterium Anabaena sp. strain PCC 7120. Mol Microbiol. 1998;27:1193-202.

\section{Submit your next manuscript to BioMed Central and we will help you at every step:}

- We accept pre-submission inquiries

- Our selector tool helps you to find the most relevant journal

- We provide round the clock customer support

- Convenient online submission

- Thorough peer review

- Inclusion in PubMed and all major indexing services

- Maximum visibility for your research

Submit your manuscript at www.biomedcentral.com/submit
(O) BioMed Central 